\title{
INTRODUCTION
}

\section{Response of nearshore ecosystems to the Deepwater Horizon oil spill}

\author{
Sean P. Powers ${ }^{1,2, *}$, Charles H. Peterson ${ }^{3}$, Just Cebrian ${ }^{1,2}$, Kenneth L. Heck Jr. ${ }^{1,2}$ \\ ${ }^{1}$ Department of Marine Sciences, University of South Alabama, 5871 USA Drive North, Mobile, AL 36688, USA \\ ${ }^{2}$ Dauphin Island Sea Lab, 101 Bienville Blvd., Dauphin Island, AL 36528, USA \\ ${ }^{3}$ Institute of Marine Sciences, University of North Carolina at Chapel Hill, Morehead City, NC 28557, USA
}

\begin{abstract}
Nearshore coastal ecosystems are among the most productive environments on the planet but are threatened as a result of sea level rise, human development and pollution. These ecosystems often act as a sink for contaminants released into the open ocean as documented during the 2010 Deepwater Horizon oil spill. The geographic extent (1000s of $\mathrm{km}$ of potentially impacted beaches and marshes) and duration ( $87 \mathrm{~d}$ of oil release) of this oil spill as well as the related response and clean-up activities were unprecedented. Six years after the spill, studies supported by the Deepwater Horizon Natural Resources Damage Assessment as well as other independent investigations have elucidated many of the consequences of one of the world's largest oil spills. Understanding these impacts required the integration of multiple marine disciplines (e.g. physical oceanography, zoology, botany, toxicology, geospatial analysis and modeling). The contributions to this Theme Section highlight 4 key findings that are critical in assessing and responding to future oil spills: (1) organismal level effects were documented across the full range of trophic levels in areas that experienced heavy oiling; (2) degradation or loss of habitat-forming species represents a pathway to long-term direct and indirect effects; (3) the loss and degradation of these habitats result in a wide range of ecosystem service losses; and (4) response actions designed to mitigate the effects of oil often result in ecological injury. Assessment of future oil spill damages should adopt a conceptual model of injury pathways early in the impact assessment process, and this model should focus heavily on habitat-forming species.
\end{abstract}

KEY WORDS: Natural Resource Damage Assessment · NRDA · Saltmarsh · Deepwater Horizon oil spill $\cdot$ Injury $\cdot$ Environmental impact

\section{Deepwater Horizon oil spill and its effects}

The Deepwater Horizon oil spill (DWHOS) was the largest oil spill in US history and one of the largest in the world (Fig. 1), with an immense geographic footprint (1000s of $\mathrm{km}$ of shoreline oiled; Rouhani et al. 2017, this Theme Section) and temporal scale (oil release for $87 \mathrm{~d}$ ), and it challenged marine ecologists in designing assessments of its impacts. The DWHOS affected 2 different but connected ecosystems: the open ocean of the Gulf of Mexico and the nearshore

${ }^{*}$ Corresponding author: spowers@disl.org environments of the northcentral Gulf of Mexico (Peterson et al. 2012). The nearly $2000 \mathrm{~m}$ deep-water source of oil in the open ocean portion of the oil spill represented a unique event for both oil spill response and assessment of impacts to deep-water reefs and deep-sea benthic, bathypelagic, mesopelagic, epipelagic and Sargassum communities (e.g. White et al. 2012, Montagna et al. 2013, Powers et al. 2013, Fisher et al. 2014). In contrast, nearshore environments are often the final repositories of oil advected to the water's surface. Negative impacts of oil spills on indi-

() The authors 2017. Open Access under Creative Commons by Attribution Licence. Use, distribution and reproduction are unrestricted. Authors and original publication must be credited. 


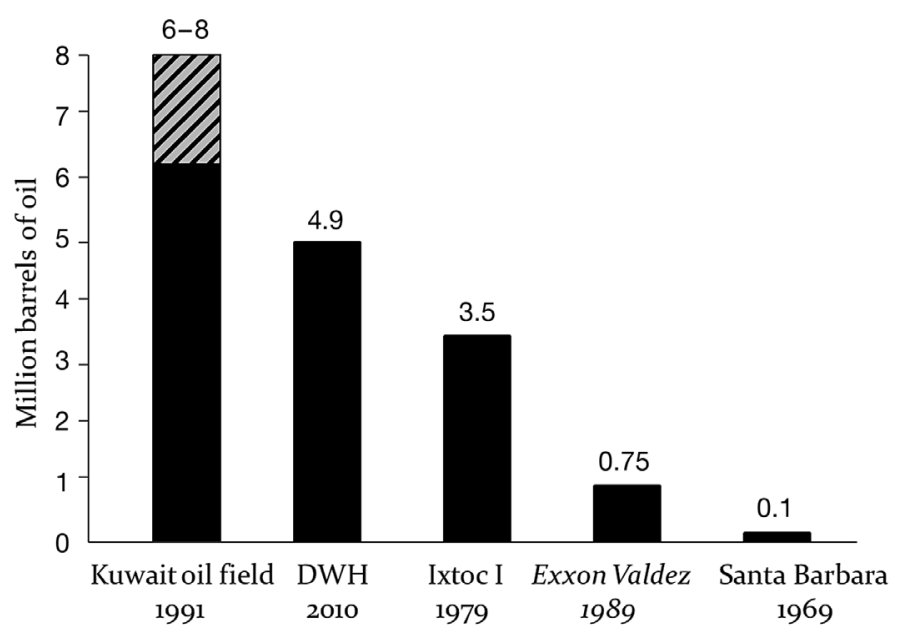

Fig. 1. Comparative oil volumes released during major oil spills throughout the world. Kuwait oil fields (Gulf War, Kuwait), Deepwater Horizon (DWH) (Northern Gulf of Mexico), Ixtoc I (Southern Gulf of Mexico), Exxon Valdez (Prince

William Sound, Alaska) and Santa Barbara (California)

vidual species are well established in nearshore environments and include lethal as well as sublethal effects. Nearshore fauna is particularly susceptible to the detrimental effects of oil, which can result in reduced growth, recruitment failure, mortality and reduced fecundity (e.g. Burns \& Teal 1979, Fleeger \& Chandler 1983, DeLaune et al. 1984). Although prior studies allow for general predictions on the direction of species responses, the elucidation of injury pathways, quantification of injuries (Baker et al. 2017, this Theme Section) and scaling of restoration (Peterson \& Lipcius 2003) - all of which are necessary components of the Natural Resource Damage Assessment (NRDA) process - represented a fundamental challenge to marine ecologists investigating the DWHOS.

\section{Nearshore studies of injury from the DWHOS}

The very large temporal and spatial scale of the DWHOS prevented a comprehensive ecosystem study of injury to the full suite of natural resources potentially harmed. Even if one focused exclusively on nearshore ecosystems, ignoring the effects on offshore pelagic, mesopelagic and deep-water habitats, a comprehensive ecosystem study would need to encompass an area stretching from Texas to Florida (1000s of $\mathrm{km}$ of coastline) and sample across multiple years and multiple trophic levels at appropriate spatial and temporal scales. The lack of rigorously and/or systematically collected baseline samples (which were not possible since the scale of the spill was not known until well into the event) prevented a Before-After-Control-Impact (BACI) study design (Underwood 1991). Furthermore, available baseline data were either extremely geographically restricted, or were collected as part of fisheries assessments that were never designed to have the statistical power to detect the effects of episodic events or determine the absolute density of animals. The absence of rigorous 'before' data limited most studies about the effects of the DWHOS to reference-impact designs.

The suite of targeted studies conducted by the DWHOS NRDA demonstrated significant ecological injury to the northern Gulf of Mexico. The results of studies presented in the present Theme Section as well as other studies on the DWHOS encompass the documentation of lethal and sublethal effects of oil spills on individual taxa (see Baker et al. 2017), spanning the full range of trophic levels from microbes (Dubinsky et al. 2013) to marine mammals (Barron 2012, Schwacke et al. 2014). Although many nearshore studies showed localized impacts of the DWHOS, not all nearshore studies indicated negative responses of key species (see Fodrie et al. 2014). Of those studies that did not detect any effects, many did not include areas of heavy oiling (such as Barataria Sound or Black Bay, Louisiana), were initiated $>1$ yr after oil washed ashore, focused on highly mobile taxa for which exposure may have been limited, or defined impacts as those that only showed population-level effects. Martin (2017, this Theme Section) demonstrated that behavioral avoidance of oil (non-weathered to medium-weathered) by some species may explain some failures to detect effects in those taxa.

\section{Recovery of nearshore ecosystems from the DWHOS}

Anticipated recovery times of injured resources vary as a function of longevity of the species and impact on the habitats that the species rely upon (Baker et al. 2017, Zengel et al. 2017, this Theme Section). In general, habitat degradation or loss as a consequence of oiling or response-related activities will affect multiple generations of taxa and persist until restoration becomes effective. Several papers in this Theme Section highlight the complexity of effects that occur when habitat-forming species are injured by oiling or associated response activities. For example, Powers et al. (2017a) demonstrated how the loss of fringing oyster reef as a result of the oil spill can accelerate coastal erosion of marsh habitat. 
Kenworthy et al. (2017) documented a loss of over $0.4 \mathrm{~km}^{2}$ of seagrass meadows in the Chandelier Islands, Louisiana, as a result of the oil spill. Powers et al. (2017b) and Grabowski et al. (2017) demonstrated the loss of some 1.2 to 3 billion adult oysters from subtidal reefs in Louisiana. Studies conducted as part of the NRDA (Hester et al. 2016) as well as other investigations (e.g. Silliman et al. 2012) indicated substantial habitat degradation and loss resulting from accelerated erosion of coastal saltmarshes. Changes in the quantity and quality of essential habitats will directly affect many ecosystem services (e.g. nutrient regulation, fish habitat functions, shoreline stabilization, denitrification and carbon sequestration).

Studies published in this Theme Section and elsewhere expand upon the paradigms already established based on the Exxon Valdez oil spill on nearshore communities and show that: (1) organismal effects of heavy oiling occur across the full range of trophic levels; (2) oiling of foundational species or 'ecosystem engineers' can result in complex and long-term direct and indirect negative effects on nearshore ecosystems (Peterson et al. 2003); (3) ecological injury to biogenic habitats can result in loss of ecosystem services that cascade and affect other habitats and processes (Powers et al. 2017a); and (4) shoreline response activities intended to remove or mitigate the effects of oil are also associated with negative impacts on habitat-forming species (Driskell et al. 2001, Martínez et al. 2012, Peterson et al. 2012, Grabowski et al. 2017, Michel et al. 2017, this Theme Section, Powers et al. 2017a,b).

\section{Preparing for future oil spills}

Assessments of ecological injury after future oil spills should develop and employ a conceptual model of injury pathways early in the assessment, and this model should focus heavily on habitat-forming species. Baker et al. (2017) provides the conceptual model adopted after the synthesis of results from the DWHOS. Such a conceptual model can also direct response action by prioritizing critical habitats in which oiling is likely to result in substantial habitat degradation or loss. In areas of intense oil and gas development or transport, resource managers should be proactive in adopting conceptual models of potential oil spills. Such models can strengthen the planning of response activities for future oil spills and direct researchers in establishing baseline data that can be used in future ecological assessments of oil spill effects.
The lack of baseline data for many of the natural resources affected by DWH oil and response activities prevented a full assessment of the long-term effects. Pennings et al. (2016) demonstrated how baseline data on marsh periwinkles can be used to support a conclusion of large-scale recruitment failure following the DWHOS. Similar recruitment failure likely resulting from the DWHOS occurred for oyster populations in the area (Grabowski et al. 2017), but the paucity of baseline data limited the power of such analyses.

Finally, any conceptual model should also include the potential effects from clean-up and response actions. Balancing the need to remove contaminants from the environment and the environmental damage and ecosystem costs associated with such response actions will always be a challenge for resource managers. Adoption of realistic conceptual models before the spill could allow the simulation of effects arising from the response actions. Minimizing long-term impacts to key habitat-forming species should be a goal of any assessment.

Acknowledgements. Funding was provided by the Federal and State Natural Resource Agencies' (Trustees') Natural Resource Damage Assessment (NRDA) for the DWH oil spill through the National Oceanic and Atmospheric Administration Damage Assessment, Remediation and Restoration Program. Some of the information presented was used in the development of the Draft Programmatic Damage Assessment and Restoration Plan/Draft Programmatic Environmental Impact Statement (PDARP, DWH Trustees, 2015). The opinions expressed by the authors are their own and do not necessarily reflect the opinion or policy of the US Government. Any use of trade, firm, or product names is for descriptive purposes only and does not imply endorsement by the US Government.

\section{LITERATURE CITED}

Baker MC, Steinhoff MA, Fricano GF (2017) Integrated effects of the Deepwater Horizon oil spill on nearshore ecosystems. Mar Ecol Prog Ser 576:219-234

Barron MG (2012) Ecological impacts of the Deepwater Horizon oil spill: implications for immunotoxicity. Toxicol Pathol 40:315-320

* Burns KA, Teal JM (1979) The West Falmouth oil spill: hydrocarbons in the salt marsh ecosystem. Estuar Coast Mar Sci 8:349-360

DeLaune RD, Smith CJ, Patrick WH, Fleeger JW, Tolley MD (1984) Effect of oil on salt marsh biota: methods for restoration. Environ Pollut Ser A 36:207-227

Driskell WB, Ruesink JL, Lees DC, Houghton JP, Lindstrom SC (2001) Long-term signal of disturbance: Fucus gardneri after the Exxon Valdez oil spill. Ecol Appl 11: 815-827

Dubinsky EA, Conrad ME, Chakraborty R, Bill M and others (2013) Succession of hydrocarbon-degrading bacteria in 
the aftermath of the Deepwater Horizon oil spill in the Gulf of Mexico. Environ Sci Technol 47:10860-10867

Fisher CR, Hsing PY, Kaiser CL, Yoerger DR and others (2014) Footprint of Deepwater Horizon blowout impact to deep-water coral communities. Proc Natl Acad Sci USA 111:11744-11749

Fleeger JW, Chandler GT (1983) Meiofauna responses to an experimental oil spill in a Louisiana salt marsh. Mar Ecol Prog Ser 11:257-264

Fodrie FJ, Able KW, Galvez F, Heck KL and others (2014) Integrating organismal and population responses of estuarine fishes in Macondo spill research. Bioscience 64: 778-788

*Grabowski JH, Powers SP, Roman H, Rouhani S (2017) Potential impacts of the 2010 Deepwater Horizon oil spill on subtidal oysters in the Gulf of Mexico. Mar Ecol Prog Ser 576:163-174

Hester MW, Willis JM, Rouhani S, Steinhoff MA, Baker MC (2016) Impacts of the Deepwater Horizon oil spill on the salt marsh vegetation of Louisiana. Environ Pollut 216: 361-370

Kenworthy WJ, Cosentino-Manning N, Handley L, Wild M, Rouhani S (2017) Seagrass response following exposure to Deepwater Horizon oil in the Chandeleur Islands, Louisiana (USA). Mar Ecol Prog Ser 576:145-161

Martin CW (2017) Avoidance of oil contaminated sediments by estuarine fishes. Mar Ecol Prog Ser 576:125-134

Martínez ML, Feagin RA, Yeager KM, Day J and others (2012) Artificial modifications of the coast in response to the Deepwater Horizon oil spill: quick solutions or long term liabilities? Front Ecol Environ 10:44-49

*Michel J, Fegley SR, Dahlin JA, Wood C (2017) Oil spill response-related injuries on sand beaches: when shoreline treatment extends the impacts beyond the oil. Mar Ecol Prog Ser 576:203-218

Montagna PA, Baguley JG, Cooksey C, Hartwell I and others (2013) Deep-sea benthic footprint of the Deepwater Horizon blowout. PLOS ONE 8:e70540

Pennings SC, Zengel S, Oehrig J, Alber M and others (2016) Marine ecoregion and Deepwater Horizon oil spill affect recruitment and population structure of a saltmarsh snail. Ecosphere 7:e01588

Peterson CH, Lipcius RN (2003) Conceptual progress towards predicting quantitative ecosystem benefits of ecological restorations. Mar Ecol Prog Ser 264:297-307
Peterson CH, Rice SD, Short JW, Esler D, Bodkin JL, Ballachey BE, Irons DB (2003) Long-term ecosystem response to the Exxon Valdez oil spill. Science 302:2082-2086

* Peterson $\mathrm{CH}$, Anderson SS, Cherr GN, Ambrose RF and others (2012) A tale of two spills: novel science and policy implications of an emerging new oil spill model. Bioscience 62:461-469

* Powers SP, Hernandez FJ, Condon RH, Drymon JM, Free CM (2013) Novel pathways for injury from offshore oil spills: direct, sublethal and indirect effects of the Deepwater Horizon oil spill on pelagic Sargassum communities. PLOS ONE 8:e74802

* Powers SP, Rouhani S, Baker MC, Roman H and others (2017a) Ecosystem services are lost when facilitation between two ecosystem engineers is compromised by oil. Mar Ecol Prog Ser 576:189-202

* Powers SP, Grabowski JH, Roman H, Geggel A, Rouhani S, Oehrig J, Baker M (2017b) Consequences of large-scale salinity alteration during the Deepwater Horizon oil spill on subtidal oyster populations. Mar Ecol Prog Ser 576: 175-187

* Rouhani S, Baker MC, Steinhoff M, Zhang M and others (2017) Nearshore exposure to Deepwater Horizon oil. Mar Ecol Prog Ser 576:111-124

* Schwacke LH, Smith CR, Townsend FI, Wells RS and others (2014) Health of common bottlenose dolphins (Tursiops truncatus) in Barataria Bay, Louisiana, following the Deepwater Horizon oil spill. Environ Sci Technol 48: 93-103

* Silliman BR, van de Koppel J, McCoy MW, Diller J and others (2012) Degradation and resilience in Louisiana salt marshes after the BP-Deepwater Horizon oil spill. Proc Natl Acad Sci USA 109:11234-11239

*Underwood AJ (1991) Beyond BACI: experimental designs for detecting human environmental impacts on temporal variations in natural populations. Mar Freshw Res 42: 569-587

White HK, Hsing PY, Cho W, Shank TM and others (2012) Impact of the Deepwater Horizon oil spill on a deepwater coral community in the Gulf of Mexico. Proc Natl Acad Sci USA109:20303-20308

* Zengel S, Weaver J, Pennings SC, Silliman B and others (2017) Five years of Deepwater Horizon oil spill effects on marsh periwinkles Littoraria irrorata. Mar Ecol Prog Ser 576:135-144 